\title{
Online Teaching During COVID-19: An Opinion Analysis of Student-Teachers
}

\author{
Sk Samsul Alli ${ }^{1}$ and Pravat Kumar Sahoo ${ }^{2 *}$ \\ ${ }^{1}$ Lecturer in Education, DIET, Jajpur, Dolipur, Odisha, India \\ ${ }^{2}$ Research Scholar, Department of Education, Central University of Punjab, India \\ "Corresponding author: 1992pravat@gmail.com
}

Revised: $24-07-2021$

\author{
Received: $21-05-2021$
}

\begin{abstract}
In the pandemic situation, students of all stages of education are facing number of problems to get education through online mode. If we talk about the teacher training institutes, the main purpose is to develop certain competencies among student- teachers to become good teachers through practical situation. Providing practical platform is impossible in this uncertain situation. Hence, to minimize the effect of this pandemic, online teaching learning process is continuing in every institution. But, sudden shift of teaching-learning process arises many questions in the mind of investigators such as how fare this online learning helpful for enhancing knowledge and skills among the student-teachers, what will be the opinion of students-teachers towards this teaching environment etc. To search the above curiosities the present study is conducted. For analyzing the opinion of student-teachers, total 150 student-teachers randomly selected from teacher training institutes of Odisha. The finding of the study revealed that student-teachers have favorable opinion towards online teaching during COVID-19 and there is no difference between the opinion of male and female student-teachers towards online teaching. Regarding the problems faced by students during online teaching are technical issues during online class such as connection issue, audio quality, video clarity etc., they are not able to afford a smart phone and its maintenance; and sometime they face health issues like eye pain, headache, fatigue etc. The study also suggested that teacher educators should try to minimize the issues face by students to access online teaching and should organize technology friendly program where the educators teach them how to use effectively online learning platform along with how to access e-material for their study.
\end{abstract}

Keywords: online teaching, COVID-19, student teacher, opinion analysis

Widespread of COVID-19 globally that WHO claimed as a global pandemic has caused almost every country to take some actions to hamper its spread which is known as health protocols, such as washing hands with soap, wearing mask, social distancing, and staying at home. The implementation of health protocols gave serious impacts to almost every human's life sectors. In education sector the implementation of the health protocol has forced the governments to close educational institutions from preschool to university both public and private, and enforced learning from home mode or distance learning using various e-learning platforms. The sudden shift from traditional face-to-face instruction in the classroom mode to at home base distance learning exposed the need for the teacher to increase their capacity building. The teacher is the central point of the entire educational system, desirable changes in the teaching-learning process. The whole educational activities revolve around the teacher. Found that ICT competencies of teacher. The problem of uneven access to the internet, the disparity of teacher qualifications and the lack of ICT skills are becoming a weakness Indians

\footnotetext{
How to cite this article: Alli, Sk S. and Sahoo, P.K. (2021). Online Teaching During COVID-19: An Opinion Analysis of Student-Teachers. Educational Quest: An Int. J. Edu. Appl. Soc. Sci., 12(2): 137-146.
}

Source of Support: None; Conflict of Interest: None (c) $\rightarrow$ 
distance learning activity. Despite lack of equality of ICT competence and disparity of socio economic among teachers, during pandemic there is no other way for teachers except conducting online learning. This article describes teaching during COVID-19 online learning, including online platforms they used, and their problems that they faced during the implementation.

Technology has a huge potential to furnish innovative solutions in order to make the learners able to take part in the quality learning opportunities, to access information and knowledge and fully participate in society. The effective integration of Information and Communication Technology (ICT) in the schools and classrooms can transform pedagogy and empower students (UNESCO-IESALC, 2020). Therefore, it is essential that teachers have the competencies to integrate ICT in their professional practice to make sure the equity and quality of learning. Teachers who have competencies to use ICT in their professional practice will be able to deliver quality education and to guide the development of the students' ICT competencies. However, the use of ICT in $21^{\text {st }}$ century as a media through which students develop high-order thinking and active learning was not well supported by teachers who were not ready and still in struggle to go beyond using ICT as content instruction tools (Ertmer \& Ottenbreit-Leftwich, 2013). Therefore, teachers need to develop their technological pedagogical content knowledge, and their professional know-how for ICT integration (Chai \& Hwee et al. 2019). Study by (Hung, 2016) showed that male teachers showed greater readiness in the dimension of learningtransfer self-efficacy than did female teachers. Teachers with a master's degree assigned a heavier weight to the dimension of communication selfefficacy and learning - transfer self-efficacy than did teachers with a bachelor's degree. Another finding showed that the fewer teaching years a teacher had, the higher the teacher's communication self-efficacy tended to be; and the more teaching years a teacher had, the higher the teacher's self-directed learning tended to be.

\section{Objectives}

1. To examine the opinion of student-teachers towards online teaching during COVID-19.
2. To compare the opinion of male and female student-teachers towards online teaching during COVID-19.

3. To explore the problems faced by studentteachers in online teaching during COVID-19.

\section{Research Questions}

1. What will be the opinion of student-teachers towards online teaching during COVID-19?

2. Will the male and female student-teachers differ in their opinion towards online teaching during COVID-19?

3. What are the problems faced by studentteachers in online teaching during COVID-19?

\section{METHODS AND PROCEDURE}

In order to use evidence to explain current circumstances and procedures or to make more informed plans to change such phenomena, survey research method are carried out to obtain comprehensive explanations of existing phenomena (Good, 1963). The main objective of this study is to analyze the opinion of student-teachers on online teaching during COVID-19. The investigator gathered data through research tool from studentteachers. Therefore, the investigator used survey research method to study this phenomenon.

The population of the study comprised all studentteachers are enrolled (2019-2021 session) in the secondary teacher training institute (B.Ed. Course) of Odisha. As per the NCTE list, there are 45 teacher training institutions (includes Autonomous colleges, CTEs, IASE, DIET and university) where B.Ed. students are enrolled. In order to represent the student teachers throughout the state, the investigator used simple random sampling technique (lottery method) to select five training institutes from 45 training institutes to gather the opinion of student teachers regarding this. The data were collected through online mode through Google form. In the initial phase 212 questionnaires were circulated among students but returned 179 responses. Out of 179 responses, the investigator rejected 29 questionnaires due unengaged and incomplete response. Therefore, finally the responses of 150 student-teachers were taken for analysis. Regarding the tool, the investigator prepared research tool called questionnaire for student-teachers to gather 
the opinion of student-teachers towards online teaching. To establish the content validity, the tool was sent to four experts in the field of education by mail. According to the suggestions received from experts, the tool modified to collect final data. The present study used percentage analysis method followed by thematic description techniques to analyze the collected data.

\section{ANALYSIS}

Research Q1: What will be the opinion of student-teachers towards online teaching during COVID-19?

Here the investigator analyzed the opinion of student-teachers towards online teaching during COVID-19. The percentage wise opinion of students is given in the table 1 .

Table 1, reveals the item-wise opinion of studentteachers towards the online teaching during COVID-19. The item-wise result of the interpretation of the percentage is as follows;

Item No.1: Do you like online teaching-learning process?

On this item, out of 150 student-teachers, $62.66 \%$ responded that they like online teaching learning process during COVID-19 whereas $37.33 \%$ reported that they do not like online teaching learning process during COVID-19. Hence, the majority of student-teachers $(62.66 \%)$ responded that they like online teaching learning process during COVID-19.

\section{Item No.2: Do you feel that online teaching enhances your knowledge?}

On this item, out of 150 student-teachers, $67.33 \%$ responded that they feel that online teaching enhances their knowledge during the pandemic whereas $32.66 \%$ reported opposite reaction. Hence, the majority of the student-teachers $(67.33 \%)$ reported that they feel that online teaching enhances their knowledge.

\section{Item No.3: Do you think that online teaching helps to gain deep knowledge on particular topic?}

Out of 150 student-teachers, 55.33\% of studentteachers responded that online teaching helps to gain deep knowledge on particular topic, but $44.66 \%$ reported against on this item. So, we can be concluded that more than half of the studentteachers reported that online teaching helps to gain deep knowledge on particular topic.

Table 1: Opinion of student-teachers towards online teaching during COVID-19

\begin{tabular}{|c|c|c|c|c|c|}
\hline Sl. No. & Items & Yes & $\%$ & No & $\%$ \\
\hline 1 & Do you like online teaching-learning process? & 94 & 62.66 & 56 & 37.33 \\
\hline 2 & Do you feel that online teaching enhances your knowledge? & 101 & 67.33 & 49 & 32.66 \\
\hline 3 & $\begin{array}{l}\text { Do you think that online teaching helps to gain deep knowledge on particular } \\
\text { topic? }\end{array}$ & 83 & 55.33 & 67 & 44.66 \\
\hline 4 & Do you enjoy your learning during online teaching? & 101 & 67.33 & 49 & 32.66 \\
\hline 5 & $\begin{array}{l}\text { Does online teaching platform provide you to interact effectively with your } \\
\text { teachers and peers? }\end{array}$ & 68 & 45.33 & 49 & 54.66 \\
\hline 6 & Do you think that online teaching is learner friendly? & 91 & 60.66 & 59 & 39.33 \\
\hline 7 & $\begin{array}{l}\text { Do you get chance to discuss with teachers during online teaching about your } \\
\text { doubts? }\end{array}$ & 119 & 79.33 & 31 & 20.66 \\
\hline 8 & $\begin{array}{l}\text { Do you easily access the e-learning material suggested by your teacher during } \\
\text { online learning? }\end{array}$ & 117 & 78 & 33 & 22 \\
\hline 9 & Do you have enough e-learning material to get deep understanding about topic? & 80 & 53.33 & 70 & 46.66 \\
\hline 10 & Do you satisfy with process of online assessment that are adopted by your teacher? & 113 & 75.33 & 37 & 24.66 \\
\hline 11 & Do you think that online assessment really assesses your achievement level? & 74 & 49.33 & 76 & 50.66 \\
\hline 12 & $\begin{array}{l}\text { Do you think that enough time is given to ask questions to teachers during online } \\
\text { teaching? }\end{array}$ & 98 & 65.33 & 52 & 34.66 \\
\hline 13 & Do you think the platform used by teacher is effective for learning? & 63 & 42 & 87 & 58 \\
\hline 14 & Do you get feedback from your teachers to enhance learning? & 125 & 83.33 & 25 & 16.66 \\
\hline 15 & Do you think online teaching enhances your practical knowledge on subject? & 55 & 36.66 & 95 & 63.33 \\
\hline
\end{tabular}


Item No. 4: Do you enjoy your learning during online teaching?

From 150 student-teachers $67.33 \%$ responded that enjoy learning during online teaching whereas $32.66 \%$ responded that they don't enjoy this process of teaching. Hence, it can be concluded that the maximum number of student-teachers reported that they enjoy the process of online teaching and learning.

Item No. 5: Does online teaching platform provide you to interact effectively with your teachers and peers?

On this item, only $45.33 \%$ of student-teachers reported that online teaching platform provides to interact effectively with their teachers and peers whereas $54.66 \%$ responded that online teaching platform does not provide scope to interact effectively with their teachers and peers. So, we can be concluded that majority of student-teachers reported that online teaching platform does not provide scope to interact effectively with their teachers and peers.

Item No. 6: Do you think that online teaching is learner friendly?

On this item, $60.66 \%$ responded that online teaching is learner friendly and $39.33 \%$ responded online teaching is not learner friendly. From the above report, we can be concluded that the majority of student-teachers reported that online teaching is learner friendly.

Item No. 7: Do you get chance to discuss with teachers during online teaching about your doubts?

Out of $150,79.33 \%$ of student-teachers reported that they get chance to discuss with teachers during online teaching about your doubts whereas $20.66 \%$ students not favor of this item. Hence, the maximum number of student-teachers reported that they get chance to discuss with teachers during online teaching about your doubts.

Item No 8: Do you easily assess the e-learning material suggested by your teacher during online learning?

From the total number of respondents, the maximum numbers of student-teachers $(78 \%)$ reported that they are easily assess the e-learning material suggested by their teachers during online learning whereas $22 \%$ reported that they are unable to assess e-materials. We can be concluded that students were not facing problems in term of accessing e-learning material during online teaching.

Item No 9: Do you have enough e-learning materials to get deep understanding about topic?

On this item, $53.33 \%$ responded that they have enough e-learning materials for deep understanding about the topic and $46.66 \%$ responded that they don't have sufficient e-learning material for deep understanding of a topic. We can be concluded that they have sufficient e-learning material for acquiring deep understanding about topic.

Item No. 10: Do you satisfy with the process of online assessment that is adopted by your teacher?

On this item, $75.33 \%$ of student-teachers responded that they are satisfied with the process of online assessment whereas $24.66 \%$ report that they are not satisfied with the process of assessment. Therefore, we found that almost one-fourth of the respondents are happy with the process of online assessment.

\section{Item No. 11: Do you think that online assessment} really assesses your achievement level?

On this item, out of 150 respondents, $49.33 \%$ of student-teachers reported that online assessment really assesses their achievement level but 50.66\% reported that online assessment does not assesses their really achievement level. So, here we can be concluded half of students reported that online assessment does not assesses their really achievement level.

Item No. 12: Do you think that enough time is given to ask questions to teachers during online teaching?

Out of 150 student-teachers, $65.33 \%$ of responses are in favor of this item but, $34.66 \%$ of them don't think so. We can be concluded that majority of students reported that they get enough time to ask questions to teacher during online teaching.

\section{Item No. 13: Do you think the platform used by} teachers is effective for learning?

On this item, out of 150 student-teachers, $42 \%$ responded that the platform used by the teacher is effective whereas $58 \%$ of them not agree with this. 
Here, we can be concluded that majority of students reported that the platform used by teachers is not effective for learning.

\section{Item No 14: Do you get feedback from your teachers to enhance learning?}

Out of 150 student-teachers, $83.33 \%$ of responded favour of the item and only a few portions i.e. $16.66 \%$ of them don't think so. From this report, we can be concluded that majority of students reported that they get feedback from your teachers to enhance their learning.

\section{Item No 15: Do you think online teaching enhances your practical knowledge on the subject?}

On this item, $36.66 \%$ of student-teachers reported that they enhance their practical knowledge through this virtual mode of teaching learning process whereas $63.33 \%$ responded negatively towards this item. So, we can be concluded that majority of students reported that online teaching does not enhance their practical knowledge.

From the above analysis, we conclude that the majority of student-teachers responded that they like online teaching learning process during COVID-19 because this platform enhances their knowledge and helps to gain deep knowledge on particular topic. Though, maximum number of student-teachers reported that they enjoy the process of online teaching and learning but this platform does not provide scope to interact effectively with their teachers and peers. Further, majority of student-teachers reported that online teaching is learner friendly because they do not face problems in term of accessing e-learning material during online teaching. Though majority of students reported that they satisfied with the process of online assessment but this process does not assesses their really achievement level. Majority of students reported that the platform used by teachers is not effective for learning. Majority of students reported that they get feedback from your teachers to enhance their learning. By analyzing the above opinion of students, it revealed that studentteachers have favorable opinion towards online teaching during COVID-19. The above responses of student-teacher presented in the graph 1 .

By analyzing the above opinion of student-teachers towards online teaching presented in Fig. 1, it revealed that student-teachers have favorable opinion towards online teaching during COVID-19.

\section{Research Q2: Will the male and female student-teachers differ in their opinion towards online teaching during COVID-19?}

Here the investigator compared the opinion of male and female student-teachers towards online teaching which are presented in the table 2.

Table 2, reveals the comparison of item-wise opinion of male and female student-teachers towards the online teaching during COVID-19. The item-wise result of the interpretation of the percentage is as follows:

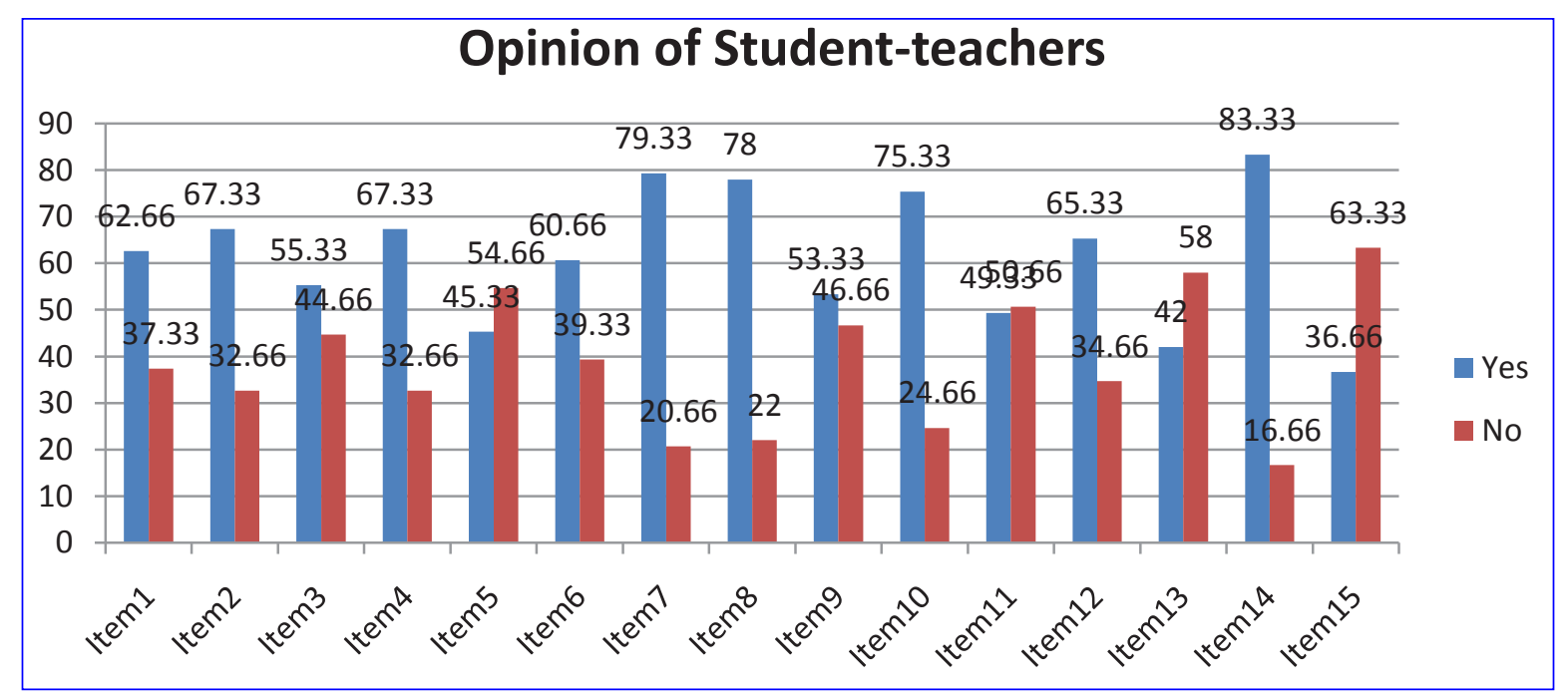

Fig. 1: Opinion of student-teachers towards online teaching 
Table 2: opinion of male and female student-teachers towards online teaching

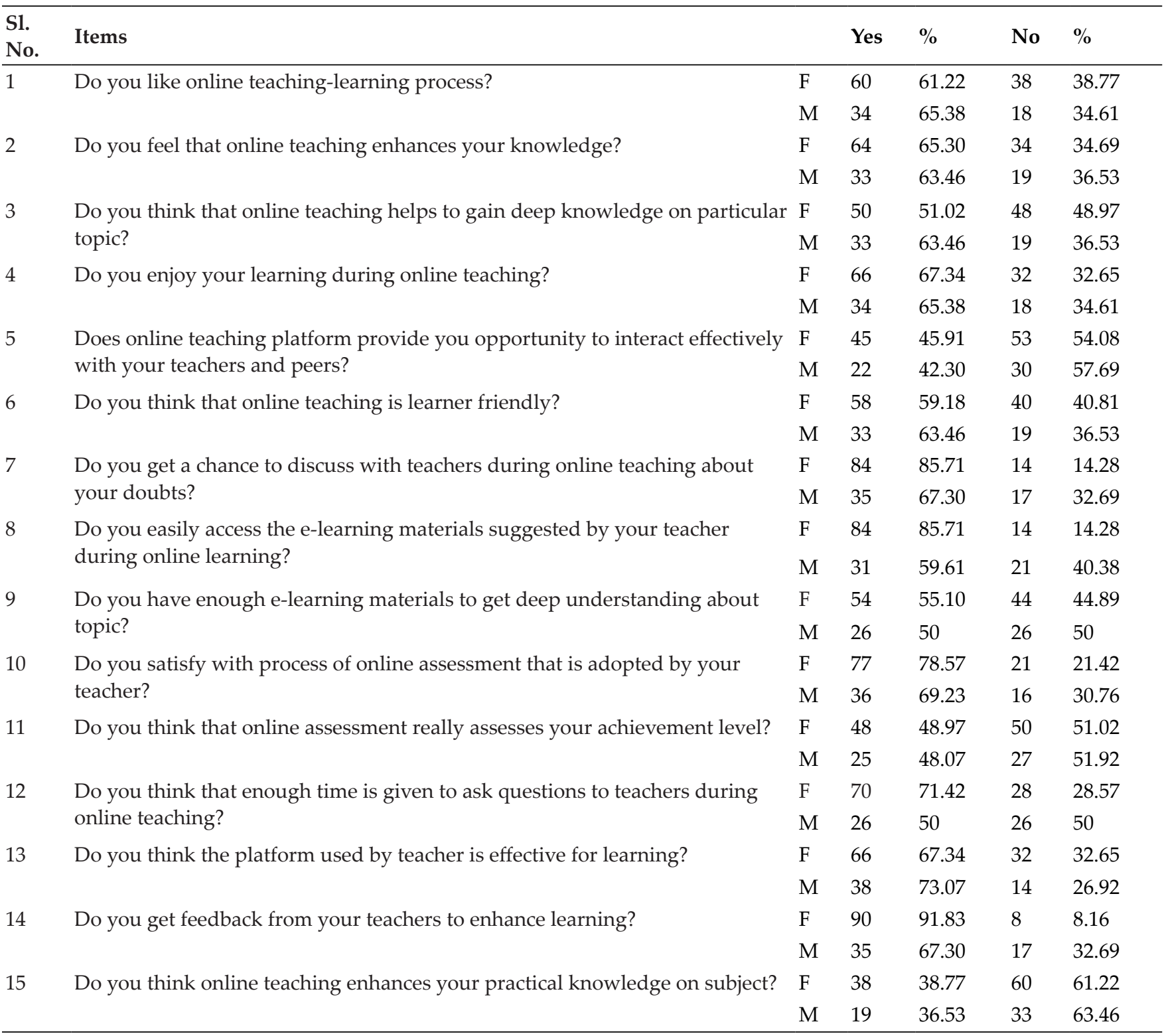

\section{Item No.1: Do you like online teaching-learning process?}

On this item, out of 98 female student-teachers, $61.22 \%$ responded that they like online teaching learning process during COVID-19 whereas 38.77\% reported that they do not like online teaching learning process during COVID-19. Further, 61.22\% male student-teachers out of 52 responded that they like online teaching learning process during COVID-19 whereas $34.61 \%$ reported that they do not like online teaching learning process during COVID-19. Hence, the majority of male and female student-teachers responded that they like online teaching learning process during COVID-19. There is no huge difference in the opinion of male and female student teachers on this item.

\section{Item No.2: Do you feel that online teaching enhances your knowledge?}

On this item, out of 98 female student-teachers, $65.30 \%$ agreed that the online teaching enhance their knowledge during pandemic whereas 34.69\% do not agreed that the online teaching enhance their knowledge during pandemic. Further, out of 52 male student-teachers, $63.46 \%$ responded that online teaching enhances their knowledge whereas $36.53 \%$ responded that they do not feel that online teaching enhances their knowledge. Hence, the 
majority of male and female student-teachers reported that during COVID-19 situation online teaching enhances their knowledge.

\section{Item No.3: Do you think that online teaching helps to} gain deeper knowledge on particular topic?

On this item, out of 98 female student-teachers, $51.02 \%$ reported that online teaching helps them to gain deeper knowledge on particular topic whereas $48.97 \%$ do not think the same. Further, out of 52 male student-teachers, $63.46 \%$ gave their opinion that they think online teaching help them to gain deeper knowledge on particular topic whereas $36.53 \%$ do not think the same. Hence, it can be concluded the majority female and male studentteachers reported that online teaching helps them to gain deeper knowledge on particular topic.

\section{Item No.4: Do you enjoy your learning during online teaching?}

On this item, out of 98 female student-teachers, $67.34 \%$ responded that they enjoyed the learning during online teaching whereas $32.65 \%$ responded that they did not enjoy the learning process during online teaching. Further out of 52 male studentteachers, $65.38 \%$ enjoyed the online teaching process whereas $34.61 \%$ did not enjoy the online teaching process. Hence, majority of male and female teacherstudents enjoyed the online teaching learning.

Item No.5: Dose online teaching platform provide you to interact effectively with your teachers and peers?

On this item, out of 98 female student-teachers $45.91 \%$ agreed that online teaching platform provides facilities to interact effectively with teachers and peers but $54.08 \%$ did not agree with it. Further, out of 52 male student-teachers $42.30 \%$ agreed that they interacted effectively with their teachers and peers during online teaching whereas $57.69 \%$ did not agree with this item. So, here we can be concluded that maximum number of the male student-teachers reported that online teaching platform provides them opportunity to interact effectively with teachers and peers as compared to female students.

\section{Item No.6: Do you think that online teaching is} learner friendly?

On this item, out of 98 female student-teachers
$59.18 \%$ thought that online teaching is learner friendly whereas $40.81 \%$ did not think that online teaching is learner friendly. Further, out of 52 male student-teachers $63.46 \%$ believed that online teaching is learner friendly whereas $36.53 \%$ did not believe so. According to this data, most of the male and female student-teachers reported that online teaching is learner friendly.

\section{Item No.7: Do you get chance to discuss with teachers during online teaching about your doubts?}

On this item, out of 98 female student-teachers $85.71 \%$ said that they got chance to discuss their doubts with teachers whereas very few $14.28 \%$ said, they did not get a chance to discuss their doubts. In case of male student-teachers, out of $52,67.30 \%$ agreed to the fact that they got a chance to discuss their doubts whereas $32.69 \%$ did not agree with this item. From this data we can be concluded, majority of female student-teachers agreed to the fact that they got chance to discuss doubts with their teachers as compared to male student-teachers.

\section{Item No.8: Do you easily access the e-learning materials suggested by your teacher during online learning?}

On this item, out of 98 female student-teachers $85.71 \%$ easily accessed the e-learning materials suggested by their teacher whereas $14.28 \%$ did not easily access the e-learning materials. Further out of 52 male student-teachers $59.61 \%$ easily accessed the suggested e-learning materials whereas $40.38 \%$ did not easily access the suggested e-learning materials. Hence we can be concluded that the opinion of fame students differ to their male counter on this item.

\section{Item No.9: Do you have enough e-learning materials} to get a deep understanding about topic?

On this item, out of 98 female student-teachers $55.10 \%$ voted that they have enough e-learning materials to get a deep understanding of topic whereas $44.89 \%$ voted that they did not have enough e-leaning materials. But in case of male student-teachers the ratio is 50:50, means half of them reported that they have enough e-learning materials and other half voted that they did not have enough e-leaning materials. If we analyze the report, overall it is seen that half of the male and female student-teachers reported that they have enough 
e-learning materials to get a deep understanding about topics.

Item No.10: Do you satisfy with the process of online assessment that is adopted by your teacher?

On this item, out of 98 female student-teachers $78.57 \%$ responded that they satisfied with the process of online assessment that are adopted by their teacher whereas $21.42 \%$ responded that they did not satisfy with the assessment process. Further out of 52 male student-teachers $69.23 \%$ responded in favor of online assessment process whereas 30.76\% responded that they are not satisfied with the online assessment process. Therefore, most of the female student-teacher satisfied with the process of online assessment that is adopted by their teachers as compared to male students.

\section{Item No.11: Do you think that online assessment really assesses your achievement level?}

On this item, out of 98 female student-teachers $48.97 \%$ responded that they thought online assessment really assesses their achievement level whereas $51.02 \%$ responded that they did not think that online assessment really assesses their achievement level. Further out of 52 male studentteachers $48.97 \%$ thought that online assessment assesses their achievement level perfectly whereas $51.02 \%$ thought that their achievement level can not perfectly assessed by online assessment. From this report we can concluded that there is no difference between the opinion of male and female student teacher on this item.

\section{Item No.12: Do you think that enough time is given to ask questions to teachers during online teaching?}

On this item, out of 98 female student-teachers $71.42 \%$ responded that enough time is given to ask questions to teachers during online teaching whereas $28.57 \%$ responded that they are not given enough time to ask questions to teachers during online teaching. Further, out of 52 male studentteachers $50 \%$ responded that they are given time to ask questions and rest $50 \%$ said they are not given sufficient amount of time to ask questions to teachers during their online teaching. Hence, majority of female student-teachers reported in the favor of this item as compared to male studentteachers.
Item No.13: Do you think the platform used by teacher is effective for learning?

On this item, out of 98 female student-teachers $67.34 \%$ replied that online platform used by teacher is effective for learning whereas $32.65 \%$ replied that they did not think the platform is effective. Further, out of 52 male student-teachers 73.07 replied that online platform used by teacher is effective whereas $26.92 \%$ replied they are not satisfied with the platform used by teacher for learning purpose. Hence, there is slightly difference between the opinion of male and female student-teachers in relation to effectiveness of online platform used by teacher for learning.

Item No.14: Do you get feedbacks from your teachers to enhance learning?

On this item, out of 98 female student-teachers, $91.83 \%$ responded that they got feedbacks from teachers whereas $8.16 \%$ responded that they did not get any feedbacks from teachers. Further out of 52 male student-teachers, $67.30 \%$ responded that they got feedbacks from their teachers whereas 32.69\% responded that they did not get any feedbacks from their teacher during online learning to enhance their learning. So, we can see that most of the female students reported that they get feedbacks from their teachers during online learning process as compared to male student-teacher.

\section{Item No.15: Do you think online teaching enhances your practical knowledge on subject?}

On this item, out of $98,38.77 \%$ female studentteachers reported that by online teaching they can enhance their practical knowledge on subjects but $61.22 \%$ students denied on the fact that practical knowledge can be enhanced by online teaching. Further out of 52 male student-teachers, $36.53 \%$ agreed that the practical knowledge can be enhanced by online teaching whereas $63.46 \%$ said that the online teaching is not helpful to enhance their practical knowledge on subjects. From this we can be concluded that majority of male and female student-teachers reported that online teaching is not so helpful for developing the practical knowledge on any subject.

From the above comparisons, it revealed that the majority of male and female student-teachers responded that they like online teaching learning 
process during COVID-19 because it enhances their knowledge and helps them to gain deeper knowledge on particular topic. Majority of male and female teacher-students enjoyed the online teaching learning. Further, maximum number of the male student-teachers reported that online teaching platform provides the opportunity to interact effectively with teachers and peers as compared to female students. Majority of female student-teachers agreed to the fact that they got chance to discuss doubts with their teachers and satisfied with the process of online assessment as compared to male student-teachers. Half of the male and female student-teachers reported that they have enough e-learning materials to get a deep understanding about topics most of the female students reported that they get feedbacks from their teachers during online learning process as compared to male student-teacher. In relation to gain practical knowledge, majority of male and female studentteachers reported that online teaching is not so helpful for developing the practical knowledge on any subject. By looking on the above comparison, it revealed that there is no difference between the opinion of male and female student-teachers towards online teaching.

\section{Research Q3: What are the problems faced by student-teachers in online teaching during COVID-19?}

To explore this research question, investigator framed one subjective question regarding this. So as the responses given by 150 student-teachers on this question, the genuine problems faced by them regarding assessing online teaching learning platform during COVID-19 are given in the following:

(a) Online teaching is not effective as compared to physical teaching because it has lack scope for acquiring practical knowledge and deep understanding.

(b) Majority students (74\%) reported that they face technical issues during online class such as connection issue, audio quality, video clarity etc.

(c) There is a lack of interaction between students and teacher because it is impossible to scatter the needs of every student in online teaching. (d) Many students (81\%) reported that they are not able to afford a smart phone and its maintenance.

(e) Majority of students (61\%) also reported that sometime they face health issues like eye pain, headache, fatigue etc. because they have to attain more than three classes per day.

\section{DISCUSSION AND CONCLUSION}

The sudden shift from traditional face-to-face instruction in the classroom mode to at home base distance learning highlighted the need for teachers to expand their capacity. The teacher is the heart of the educational system that brings desirable changes in the teaching-learning process. The whole educational activities revolve around the teacher. The effective integration of Information and Communication Technology (ICT) in classrooms can transform pedagogy which empowers the students (UNESCO-IESALC, 2020). As a result, it is critical that teachers have the skills to integrate ICT into their professional practice in order to ensure equality and quality teaching learning. The main aim of the study is to analyze the opinion of student-teachers towards online teaching. For this, the investigator collected the opinion of 150 studentteachers. The finding of the study revealed that student-teachers have favorable opinion towards online teaching during COVID-19 and there is no difference between the opinion of male and female student-teachers towards online teaching. Regarding the problems faced by students during online teaching are technical issues during online class such as connection issue, audio quality, video clarity etc., they are not able to afford a smart phone and its maintenance, sometime they face health issues like eye pain, headache, fatigue etc. and There is a lack of interaction between students and teacher. After going through the findings, the study also suggested that teacher educators should use learner friendly online platform, try to minimize the issues face by students to access online teaching and should organize technology friendly program where the educators teach them how to use effectively online learning platform along with how to access e-material for their study. 


\section{REFERENCES}

Anees, A. 2015. Teacher education and their problems. International Journal of Academic Research in Education and Review.

Bhattacharjee, B. and Deb, K. 2016. Role of ICT in $21^{\text {st }}$ century's teacher education. International Journal of Education and Information Studies.

Chai, C.S., Hwee Ling Koh, J. and Teo, Y.H. 2019. Enhancing and modeling teachers' design beliefs and efficacy of technological pedagogical content knowledge for $21^{\text {st }}$ century quality learning. Journal of Educational Computing Research, 57(2): 360-384.

Desai, A.J. 2011. Problems of teacher education in India. International Journal for Research in Education.

Ertmer, P.A. and Ottenbreit-Leftwich, A. 2013. Removing obstacles to the pedagogical changes required by Jonassen's vision of authentic technology-enabled learning. Computers $\mathcal{E}$ Education, 64: 175-182.
Hung, M.L. 2016. Online learning readiness: Its relations to college students' changes over time, and willingness to enroll in future courses. International Journal of Technology and Human Interaction (IJTHI), 12(1): 51-62.

National Council for Teacher Education. 2009. National Curriculum Framework for Teacher Education Towards Preparing Professional and Humane Teacher. New Delhi, India.

National Council of Educational Research \& Training. 2005. National Curriculum Framework. New Delhi.

Saxena, N. 2017. The role and impact of ICT in improving the quality of education: An overview. International Journal of Engineering Sciences \& Research Technology. Retrieved from https://educationaltechnology.net/technologicalpedagogical-content-knowledge-tpack-framework 